\title{
Introduction to The Institutional Evolution of China
}

China's experience over the past four decades is not just a story of economic growth, but also one of institutional change. The most impressive event of economic reform in the past four decades has been the creation of private enterprises and the market from nowhere, through the joint efforts of the Chinese government and society in a period of one generation. This is a tremendous achievement, which has created a miracle of economic growth and brought benefits to Chinese people. This rich experience of institutional change in China needs to be explored. The reform since the late 1970s has not finished. As a result, the current political-economic system in China is a dual system, a bureaucratic-market system in which the government and the market both coexist and conflict with each other. China's economic growth in the past 40 years can be explained within the framework of this bureaucratic-market system. China matters economically and politically to the rest of the world, and understanding institutional changes in China is important for policy makers, business people, students, and researchers. In this book, I give a detailed description of the institutional evolution in China during its recent economic reform, using a large number of documents and cases. The book also provides an index to measure the scale of China's marketisation.

The central issue of China's institutional changes in the past 40 years is the relationship between government and market. Different from many existing researches which emphasise inputs of production, this book argues that institutional changes have been the most fundamental causes of China's recent economic growth. The institutional rearrangement of government and market has been crucial in this process. The government's gradual relaxation of control of the market played an extremely important role in the process of reform. The market has been the fundamental source of the economic growth in China, as the government has cleared the obstacles to the development of the market. This has resulted in rapid growth, but at the same time it has created problems of income inequality and corruption in a system without many checks and balances.

This book describes China's economic reform from 1978 to the 2010s following two theoretical frameworks: (i) Douglass North's theory 
of path dependence in institutional evolution, which explains the sequence of institutional changes in China, and (ii) a theory of political economy (developed in section 1.2), which explains an authoritarian government's decision-making in a bureaucratic-market economy like the one in China.

Path dependence exists in the process of China's institutional evolution. The reform in China experienced a circuitous path, from the creation and development of the market to stagnation and redirection of the reform. Historically, China's economic reform came from the rock bottom of the Cultural Revolution, which hurt every group in Chinese society, including government officials. This built the whole society's consensus on the need for change and resulted in the government-led reform. In the early years of reform, the government reduced its control of the society and increased incentives to the lower level of government and the society. However, such a consensus on reform has been diluted incredibly in the process of change when the expansion of the market hurts the interests of different groups of people. The nature of the bureaucratic-market system fostered corruption among government officials and business executives, and this has damaged social equity and justice. The last 15 years of reform have experienced stagnation and readjustments of government policies. This was fundamentally a result of the changing priorities of government decisions, which in turn was caused, ironically, by the improving economic situation and the loosening of government control.

This book provides a framework of a theory of political economy explaining the origin of China's reform, the political and economic forces driving the reform, and the reasoning behind the stagnation of the reform. The government has multiple targets, and political stability and economic performance have become restrictions on its behaviour. Economic performance has been an important source of legitimacy of the rule of the government. Social stability, meanwhile, has been the main target and the foundation of the existence of the government. There are two basic policy options, economic policy and social stability policy, for the government to choose. Economic policy promotes economic growth and marketisation, whereas social stability policy maintains social stability and the government's own existence. The two policies are sometimes contradictory, so the leadership has to make trade-offs. The weight of the two policies changes over time, based on the political and economic environment. The book tries to draw a theoretical boundary between the government and the market, according to two rules: (i) following the economic theory of government intervention, intervention is appropriate only if several conditions exist, including asymmetric information, externalities, natural monopoly, non-existence of markets, and absence of property rights; (ii) considering 
the institutional background, certain government interventions will be reasonable if the market is less developed and imperfect.

The economic and political reform that started in the late 1970s created a market economy, but reforms in many fields still need to be achieved. The unfinished reforms contain several serious flaws: (i) the administrative branch of the government has not been not effectively restricted; (ii) the market reform has not been completed, with upstream resource-intensified sectors still controlled by the state; (iii) large stateowned enterprises (SOEs) still dominate some key sectors, whereas private firms face high tax burdens and overregulation; (iv) farmers do not have full property rights of the land, and local government monopolises the transfer of rural land to urban uses, which causes soaring urban housing prices; (v) the nature of the bureaucratic-market system fostered corruption among government officials and business executives. The main risk in China today is the government's unrestricted power to further squeeze out the private market.

This kind of government-led economic reform using a gradual approach reduced the difficulty of reform but at the same time left the bureaucratic system largely untouched, and this has become a perennial risk to the continuation of the reform. The most recent adjustments of the ruling strategy focus on the restructuring of power within the government and restraining the behaviour of government officials. These adjustments follow the logic of government rule, rather than that of market expansion. One of the key targets of the adjustments is corruption, the main concern of Chinese society today. To fight corruption, the government took back power and used more administrative means. This move indicates a major change in the strategy of governance that has been in place since the late 1970s.

To sum up, the government-led and non-balanced political counterpart nature of the reform created a bureaucratic-market system, which fostered corruption and to some extent lost control of both the society and the supervision of government officials. A radical response of the government to corruption and a decree barrier using administrative means, may have further centralised the system. This solved some urgent problems but might hurt the long-term vitality of the Chinese economy.

In the near future it is quite possible that, in China, a strong, impersonal, and efficient government will coexist with an under-control market in the short term. This system will have the large mobilisation forces needed to reach many of its targets, such as building large public projects or developing high-tech industries by mobilising large numbers of workers, technicians, and resources. Yet the enthusiasm of the market may be more restricted, and that may have effects on the creativity of the Chinese economy. In the long run, the bureaucratic-market system 
is unstable and further political and economic reforms are needed. The role of government should further retreat from many areas; government power must be restricted, and the initiative and creativity of the market should be brought into full play. These are the many issues this book deals with. 